\title{
流動液体セルによるガスクロマトグラフィーと 赤外吸収スペクトル法の直結について
}

\author{
津田 孝雄，森 弘之，石井 大道*
}

(1969 年 4 月 2 日受理)

\begin{abstract}
ガスクロマトグラフィーと赤外吸収スペクトル法の直結化を，新たに考案した共凝縮法により，液体 セルを用いて行なった。すなわ占，分離管を出たキャリヤーガスに有機溶媒蒸気（四塩化炭素）を混合 し，乙れを小さなリービッヒ型冷却器に導き，キャリャーガスとともに分離されて溶出する試料成分を 有機溶媒蒸気といっしょに㠜縮させて液化し，試料中の各成分を溶液の形で連続的に検出用液体セルに 流入させ，その赤外吸収スペクトルをくりかえし測定する方法である。赤外分光光度計の透過率変化は 電子管式平衡記録計で記録した。測定方法は一定波数領域走查，またはいくつかの波数領域の組み合わ せをくりか元し連続的に走査して行なった。試料としてはベンゼン，オクタン，メチルイソブチルケト ン，ピロール，デカンなどを用いた。提案した方法はガスセルを用いての GC-IR 法に比べて比較的 簡単に両者の直結ができ，良好な結果を与えた。これにより迅速定性・定量分析が可能であることを見 いだした。
\end{abstract}

\section{1 緒言}

ガスクロマトグラフィー（GC） は一般に分離分析法 としては非常に有用であるが，この方法による未知混合 物試料の分析では保持容量だけが定性の指標であるので 定性分析が不確実になることを免れない，そのためマス スペクトル(法122)，赤外吸収スペクトル法3) 9) などの機 器分析の併用が研究されてきている. 赤外吸収スペクト ル法との併用については GG によって分離された各成 分を捕集して，ついでスペクトルを測定する方法334)が 一般に用いら机てきたが，この方法は時間がかかるこ と，分取の際こストが発生すること，捕集効率が低いこ と, 試料が比較的多量いることなどの欠点がある。これ らの久点を除くため GC と IR を直結する方法がとら れ，GCより溶出した試料成分を直接赤外用ガスセルに 導く方法が報告5 年さされいる. 感度を上げるくふうと して $100 \mathrm{~cm}$ の長光路セルを用いた報告》，2500〜250 $\mathrm{cm}^{-1}$ を 1 秒で走查する干涉分光器を用い, 多重走查に より感度を上げ $0.1 \mu l$ まで検出している報告がある6).

ガスセルを用いるとセルの加熱に注意を払う必要があ り，また長光路セルを用いる場合には反射鏡のよごれや 光量の損失がともなうことなどの欠点がある.

* 名古屋大学工学部応用化学科 : 名古屋市千種区不老 町
著者らはガスクロマトグラフィーと赤外吸収スペクト ル法の直結化を，新たに共凝縮法により液体セルを用い て行ない，この方法が簡便で実用的であることを見いだ したので報告する.

\section{2 実験}

共凝縮法による GC-IR 連続装置図を Fig. 1 に示し た、すなわち GGによって分離された試料各成分を含 むキャリヤーガスに有機溶媒蒸父発生装置により発生さ せた有機溶媒蒸気（四塩化炭素）を加えて混合したの ち, 適当な冷却器 (5) に導き共凝縮により液化させ, 試料中の各成分を溶液の形で検出用液体セル（6）に流

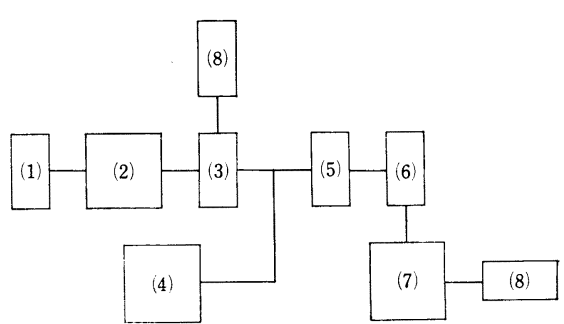

Fig. 1 Diagram of GC-IR combination system (1) $\mathrm{H}_{2}$ bomb; (2) Gas chromatograph; (3) Thermoconductance detector; (4) Generator of organic vapor ; (5) Condenser; (6) Infrared flow liquid cell; (7) Infrared spectrometer; (8) Recorder 
入させて,その赤外吸収スペクトルを連続的に測定する。 有機溶媒蒸気が通過する導管は凝縮が生じないように約 $120^{\circ} \mathrm{C}$ に加熱した. GC よりの導管と泠却器の接続はシ リコーン管を用い, 泠却器と液体セルの接続はポリエチ レン管を用いた. 赤外分光光度計は日本分光工業製 IRE（全域走查 15 分）を用いた。

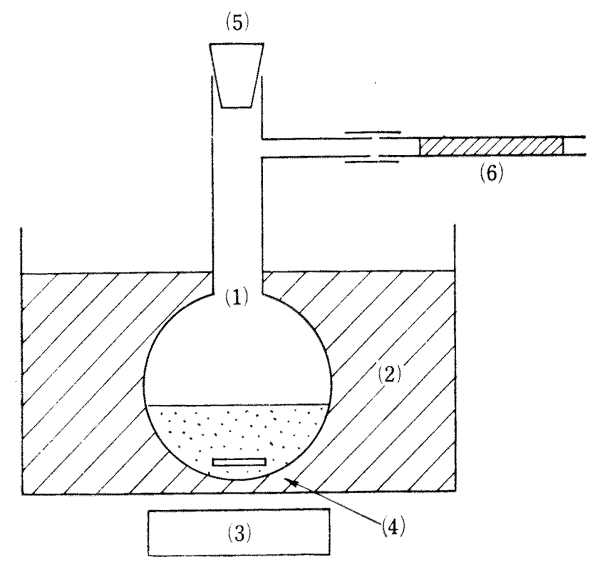

Fig. 2 Generator of organic vapor

(1) $500 \mathrm{~m} l$ flask, containing $200 \mathrm{~m} l$ of $\mathrm{CCl}_{4}$; (2) Polyethylene glycol bath, regulated with thermoregulator; (3) and (4) Magnetic stirrer; (5) Silicone rubber; (6) Resistant part, containing firebrick (40 $60 \mathrm{mesh}$ ), inner diameter $4.5 \mathrm{~mm}$, length $50 \mathrm{~cm}$

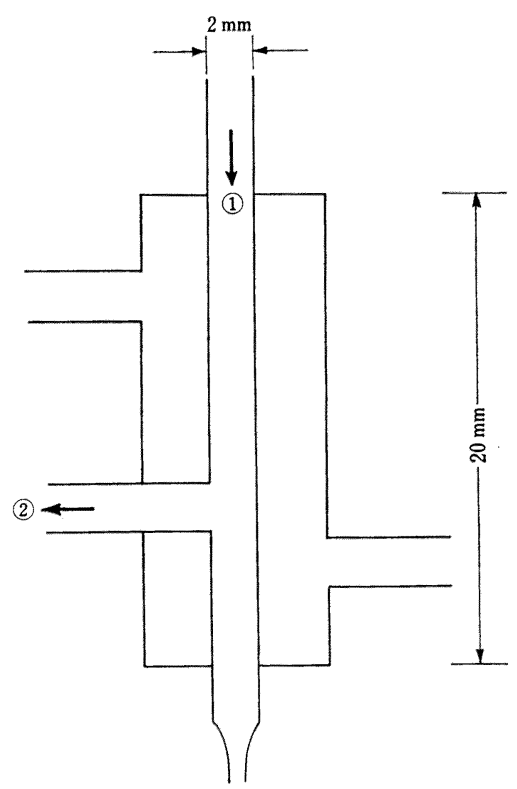

Fig. 3 A small condenser, glass made (1) Mixed gas inlet; (2) Outlet

\section{1 有機溶媒蒸気発生装置}

本実験では有機溶媒蒸気として四塩化炭素を用いた。

$500 \mathrm{ml}$ の枝付き丸底フラスコに約 $200 \mathrm{ml}$ の四塩化 炭素を入れ，こ礼をポリエチレングリコール浴で適当な 温度に保つことにより任意の一定流速を得た。

\section{2 共凝縮用冷却器}

混合ガスを凝縮液化するための冷却器は小型のガラス 製リービッヒ型のものを作製して用い，凝縮液化が完全 になるように，なた液体が内壁面に付着することなく連 続的に流下するように, さらによどみなく検出器にはい るように冷却器の大きさおよび構造について検討した結 果, Fig. 3 に示すものを用いてとの目的を達した. 泠却 は水を循謤させるか, または水水を通して泠却した空気 を送風することにより行なった。

\section{$2 \cdot 3$ 流量测定}

水素キャリヤーガス（または窒素）の流量はオリフィ スメーターで測定した. 有機溶媒蒸気の流量は冷却器で 液化した液体量を液体セルを経てから, または冷却器か ら直接メスフラスコに一定時間集め重量測定することに より得た．その際液体の蒸気圧による飛散を防ぐためほ ぼ外気としゃ断しながら，かつメスフラスコはドライア イスーメタノール寒剤に浸しながら行なった. 通常は水 素キャリヤーガスを流した状態で測定 $\left(\mathrm{CCl}_{4}\right.$ condensed と記載）したが，水素キャリヤーガスを止めた状態にお いても測定を行なった。

\section{4 流動液体セル}

液体セルは溶液がよどみなく流れることや試料溶液の 拡散を防ぐことや, 洗浄作用の効率を落とさないように 検討した結果, Fig. 4-A に示した $0.2 \mathrm{~mm}$ 厚の鉛スペ 一サーを用い, セル容積（セルスペーサーの部分）約 $17 \mu l$ の流動液体セルを用いることによりとの目的を達 した.

\section{5 透過率変化を記録計に伝える方法}

赤外分光光度計のペン駆動部に銀接点をつけ, これを $1000 \Omega$ 線型ポテンシオメーター（両端に $100 \mathrm{mV}$ の電 圧をかける）に接触させて得られる電位変化を東亜電波 工業製記録計（EPR-2TG）に入れ (Fig.5)，フルスケ ール $100 \mathrm{mV}$ (sens 1) または $50 \mathrm{mV}$ (sens 2) の記録 計感度で, 記録紙送り速度 $2 \mathrm{~cm} / \mathrm{min}$ で記録した. 測定 方法は一定波数に分光光度計を固定する方法および一定 波数領域またはいくつかの領域の組み合わせをくりかえ 


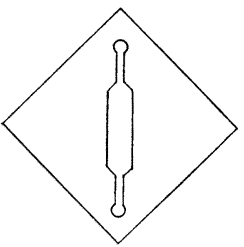

(A)

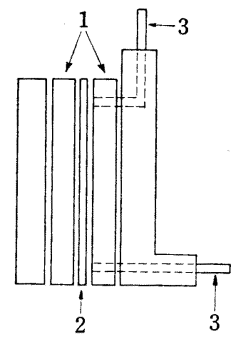

(B)
Fig. 4 Flow liquid cell

(A) Cell spacer, thickness $0.2 \mathrm{~mm}$; (B) $1: \mathrm{NaCl}$ plate; 2 : Spacer; $3:$ Stainless pipe, inner diameter $1.0 \mathrm{~mm}$

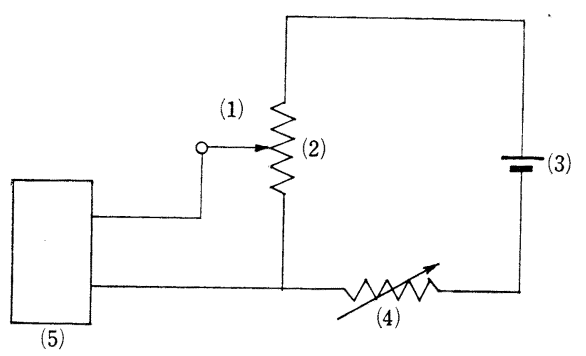

Fig. 5 A circuit of optical transmission to millivolt conversion

(1) Pen of infrared spectrometer; (2) Linear potentiometer, $1000 \Omega$; (3) Dry cell of 1.5 volt ; (4) Variable resistor, $10 \mathrm{k} \Omega$; (5) Recorder

し連続的に測定する方法を用いた。

\section{6 捕集率の測定}

冷却器で共凝縮したトルエンの四塩化炭素溶液をドラ イアイスーメタノール寒剂に浸した $10 \mathrm{ml}$ メスフラスコ に一定時間分取し，これに $10 \%$ 四塩化炭素エタノール 溶液を標線まで加光，ついで $268.5 \mathrm{~m} \mu$ の紫外吸光度測 定を行ない，検量線により捕集率を求为た。

\section{3 結果と考察}

\subsection{GG-IR 直結についての実験条件の検討}

3.1.1 共凝縮法を用いたときの試料捕集密 共凝縮 法での捕集率の検討をトルエンについて行ないその結果 をFig. 6 に示した.

これより四塩化炭素凝縮量の対数と捕集率が直線関係 にあることがわかる．窒素キャリヤーガスの流量が 21 $\mathrm{m} l / \mathrm{min}$ のとき， $75 \%$ 以上のトルエン回収率を得るに 注 $120 \mathrm{mg} / \mathrm{min}$ 以上の四塩化炭素流量 $\left(\mathrm{CCl}_{4}\right.$ condensed $)$

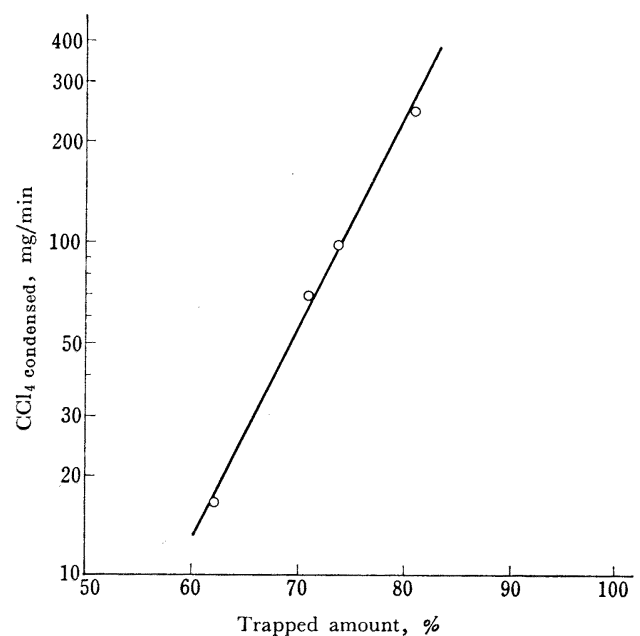

Fig. 6 Dependence of the amount of trapped toluene on $\mathrm{CCl}_{4}$ vapor flow rate at constant nitrogen carrier flow rate

$\mathrm{CCl}_{4}$ condensed : Amount of condensed $\mathrm{CCl}_{4}$ vapor by a small condenser; Carrier gas: $\mathrm{N}_{2}, 21 \mathrm{ml} / \mathrm{min}$; Cooling temp.; $30^{\circ} \mathrm{C}$; Sample : Toluene, $10 \mu l$; Column : Liquid paraffin, 30\%, $1 \mathrm{~m}$, inner diameter $4.5 \mathrm{~mm}$, temp. $130^{\circ} \mathrm{C}$; Measurement : UV

が必要である。また Fig. 6 より四塭化炭素の窒素に対 する流量比を大にすることが捕集率を高くすることであ ることがわかる。

同じ実駼条件下で有機溶媒蒸父を導入しないで泠却器 に捕集されるトルエン量を測定したところ約 10\% の捕 集率であり，また内径 $4 \mathrm{~mm}$ ，長さ $20 \mathrm{~cm}$ のガラス管 を寒郕 $\left(-78^{\circ} \mathrm{C}\right)$ に浸してトルエンの捕集を行なったと ころ，約 40\% の捕集率であった．これに比べて共㠜縮 法による捕集㤬高い捕集率が簡便に得られる点ですぐれ ている

ついで泠却器温度とトルエン捕集率および有機溶媒蒸 気凝縮率について検討した。四塩化炭素蒸気の㠜縮率法

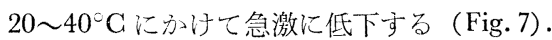

窒素キャりヤーガスがその温度に打ける苲気圧分だけ 四塩化炭素を持台去ると仮定して算出した量に比べて， 実験より求められた非凝縮量は $1.9\left(40^{\circ} \mathrm{C}\right) ， 1.53(30$ $\left.{ }^{\circ} \mathrm{C}\right), 1.35\left(20^{\circ} \mathrm{C}\right), 0.95\left(10^{\circ} \mathrm{C}\right)$ 倍である。これより

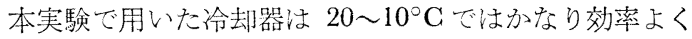

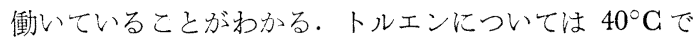
注捕集率がかなり低下するが， $20^{\circ} \mathrm{C}$ 以下ではあまり変 化が認められないので, 冷却器温度は $20^{\circ} \mathrm{C}$ 付近で以後 の実験觉行なった。

3.1.2 有機溶媒蒸気流量のクロマトグラム-IR に及 


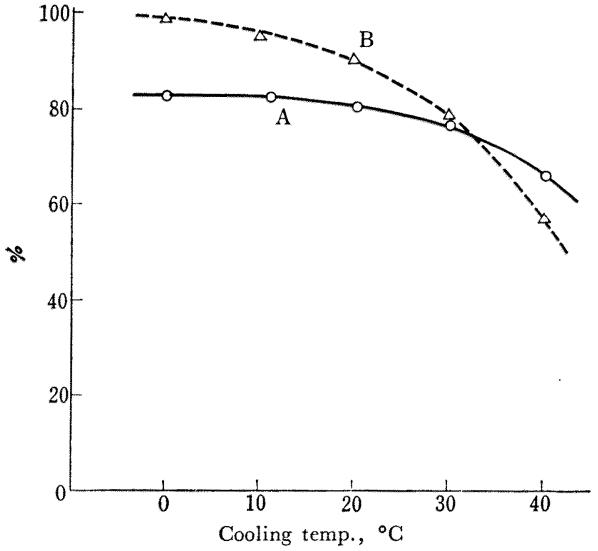

Fig. 7 Effect of cooling temp. on the amount of trapped toluene (A) and condensation of $\mathrm{CCl}_{4}$ vapor (B)

Carrier gas : $\mathrm{N}_{2}, 20 \mathrm{~m} l / \mathrm{min}$; Organic vapor: $\mathrm{CCl}_{4}$, $153 \mathrm{mg} / \mathrm{min}$; Sample : Toluene, $5 \mu l$; Column : Liquid paraffin, $30 \%, 1 \mathrm{~m}$, inner diameter $4.5 \mathrm{~mm}$, temp. $130^{\circ} \mathrm{C}$; Measurement : UV

ぼす効果 試料として $n$-ペンタンを用い，泠却器と液 体セルを接続して GC-IR を行ない，熱伝導度型検出器 (TGD) を用いてクロマトグラムを記録し（以下クロマ トグラム-TGD と記載)，さらに液体セルで溶液の赤外 吸収変化を記録（クロマトグラム-IR と記載）して，種 種の有機性溶媒蒸気流量のクロマトグラム-IR 亿及涪す 影響を検討した（Fig. 8).

四塩化炭素流量が小さいほど共凝縮により得られる試 料溶液の濃度は相詨的に高くなり，したがって強い赤外

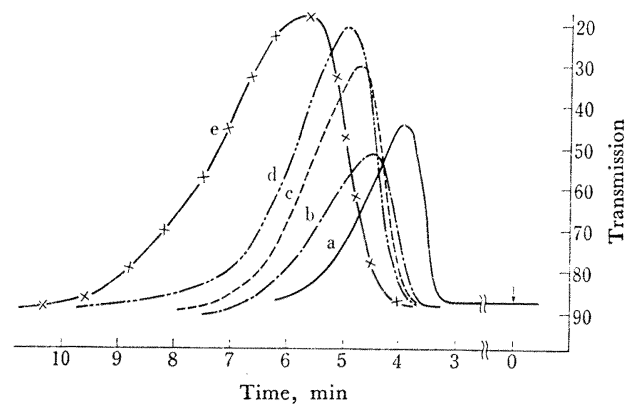

Fig. 8 Effect of $\mathrm{CCl}_{4}$ vapor flow rate on chromatogram with an IR spectrometer (a) Chromatogram with thermal conductivity detector; (b) Chromatogram with an IR spectrometer $\left(2930 \mathrm{~cm}^{-1}\right)$ at $\mathrm{CCl}_{4}$ condensed of $200 \mathrm{mg} / \mathrm{min}$; (c) $137 \mathrm{mg} / \mathrm{min}$; (d) $90 \mathrm{mg} / \mathrm{min}$; (e) $50 \mathrm{mg} / \mathrm{min}$; Carrier gas : $\mathrm{H}_{2}, 4.8 \mathrm{~m} l / \mathrm{min}$; Sample : $n$-Pentane, $6 \mu l$; Column : Dioctyl phthalate, $25 \%, 50 \mathrm{~cm}$
吸収が得られる。他方，四塩化炭素流量が少ないと液体 セル（中心部）に達するのに時間がかかり，したがって 試料の液液㧒散が生ずることや，流路への洗浄作用が弱 くなることのためにピーク幅がクロマトグラム-TCDの それに比べて大きくなる．検討の結果 $60 \sim 150 \mathrm{mg} / \mathrm{min}$ 程度の四塩化炭素流量が適当であることがわかった.

また, 泠却器と液体セルとの接続を種々の長さのポリ エチレン管（内径 $1 \mathrm{~mm}$ ）で行ない，得られたクロマト グラムを比較したところ，長い汪ど吸収帯の幅の広がり が生じたので接続管は $10 \mathrm{~cm}$ 以下が望ましいことがわか った・本実験では冷却器を直接液体セルに接続して行な った。

3.1.3 クロマトグラムの比較と遅れについて クロ マトグラム-IR の透過率目盛を吸光度目盛に直し，かつ そのピーク高およびピーク位置をクロマトグラムーTCD に合わせて双方のクロマトグラムの比較を行なった。

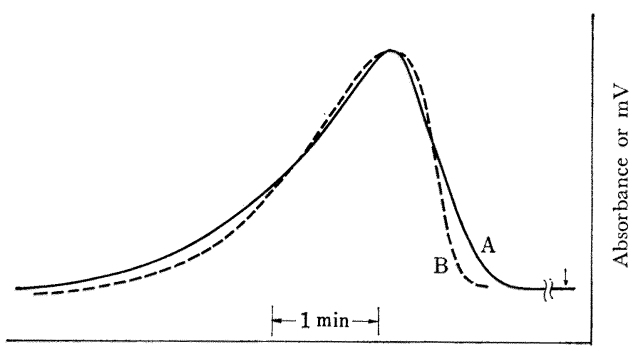

Time, $\min$

Fig. 9 Comparison of chromatograms with thermal conductivity detector and an IR spectrometer

(A) IR at $2930 \mathrm{~cm}^{-1}$; $\quad$ (B) Thermal conductivity detector. The chromatogram of (A) was plotted in absorbance and the peak position was laid upon that of (B). Carrier gas : $\mathrm{H}_{2}, 4 \mathrm{~m} / / \mathrm{min}$; Organic vapor : $\mathrm{CCl}_{4}$ condensed, $135 \mathrm{mg} / \mathrm{min}$; Sample : $n$-Pentane, $7.5 \mu l$; Column : Silicone rubber SE-30, $5 \%, 2 \mathrm{~m}$, temp. $102^{\circ} \mathrm{C}$

Fig. 9 よりクロマトグラム-IR（理論段数 150） 法ク ロマトグラム-TCD（理論段数 200）に比ベてピーク幅 分若干大きくなっているが，ほぼ良好な GC-IR ができ ていることが示されている。

クロマトグラム-IR のクロマトグラム-TCD からの 時間的遅れについて, ベンゼン, p-キシレン, デカン, クメン，n-デカノールを用いて検討したところ，n-デカ ノ一ルを除いて時間的遅れは一定であった。これより有 機溶媒蒸気として四塩化炭素を用いる場合は沸点約 170 ${ }^{\circ} \mathrm{C}$ 以下の化合物の GC-IR に適することがわかった。 


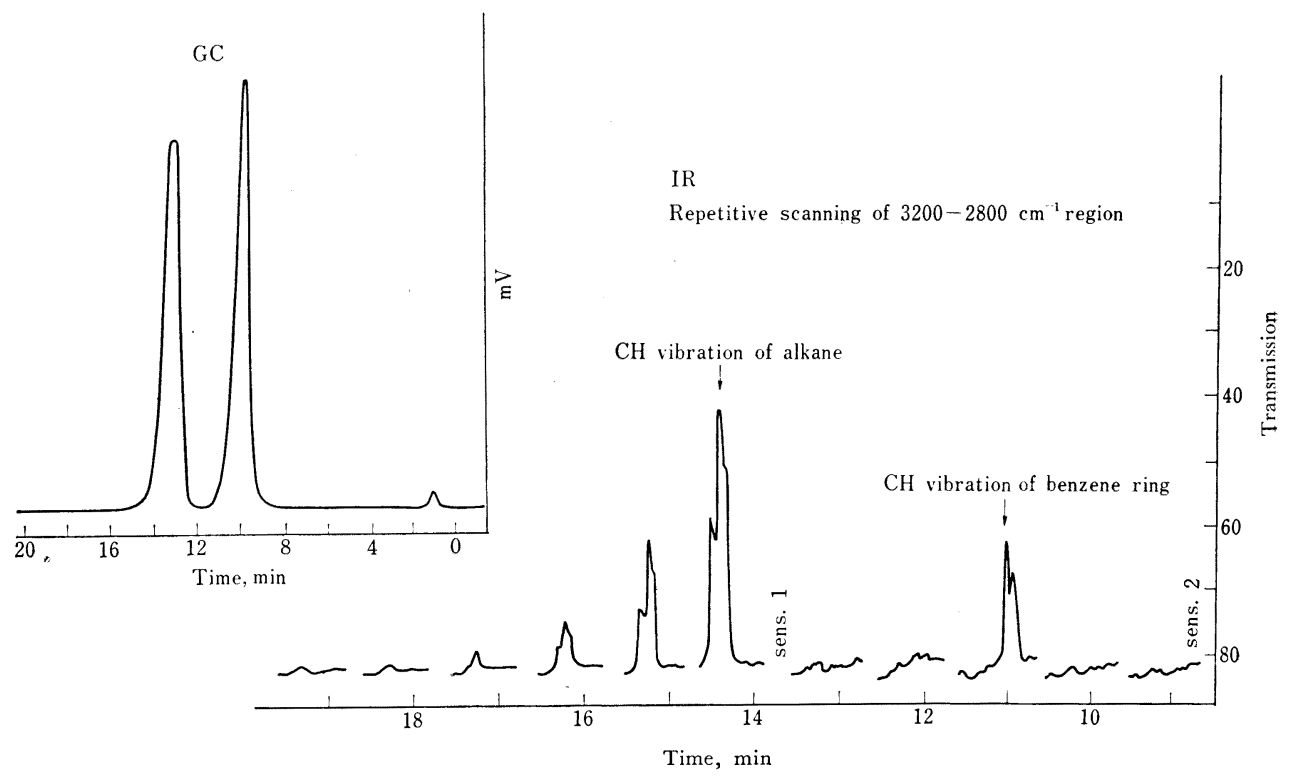

Fig. 10 GC-IR combination system

Carrier gas: $\mathrm{H}_{2}, 18 \mathrm{ml} / \mathrm{min}$; Organic vapor: $\mathrm{CCl}_{4}$ condensed $: 86 \mathrm{mg} / \mathrm{min}$; Sample : Benzene $(1.5 \mu l)$ and octane $(1.5 \mu l)$; Column : Dioctyl phthalate, $25 \%, 2.5 \mathrm{~m}$, inner diameter $4.5 \mathrm{~mm}$, temp. $147^{\circ} \mathrm{C}$; The scale of sens. $y$ is equal to $(y) \times($ transmission scale $)$.

n-デカノールは冷却器の壁面に残るために激しくテイリ ングし，他の試料の約 2 倍の時間的遅れを示した。な 㧍, 高沸点化合物への GG-IR の適用については次報で 報告する。

\subsection{GC-IR 直結による迅速分析}

Fig. 10，11 に GG-IR 直結による測定例を示した。 Fig. 10 は 3200〜 $2800 \mathrm{~cm}^{-1}$ の走査をくりかえし行なう ことにより化合物が脂肪族か芳香族か類別できることを 示しており，乙れより GC の第 1 ピークはベンゼンで 第 2 ピークはオクタンであることがわかる. Fig. 11 は 三領域の走査を連続してくりかえした例である. GGIR より第 1 ピーク注芳香族化合物で, 第 2 ピークはカ ルボニル基を持つ脂肪族化合物であり，第 3 ピークは $\mathrm{NH}$ の官能基をもつ化合物であることがわかる。これ より GC-IR により試料の迅速定性・定量分析が可能 である。

共凝縮法の特長の一つは, 試料成分の高濃縮度溶液が 得られることにある. 濃縮率注有機溶媒蒸気流量, ピー ク幅 (TCD) および試料量に依存するが，通常 1 〜 10\% の試料成分の濃縮溶液が得られる. GC-IR によりほぼ 満足すべき赤外吸収スペクトルを得るには試料各成分が $1.5 \mu l$ 程度必要である. しかし試料量については赤外分

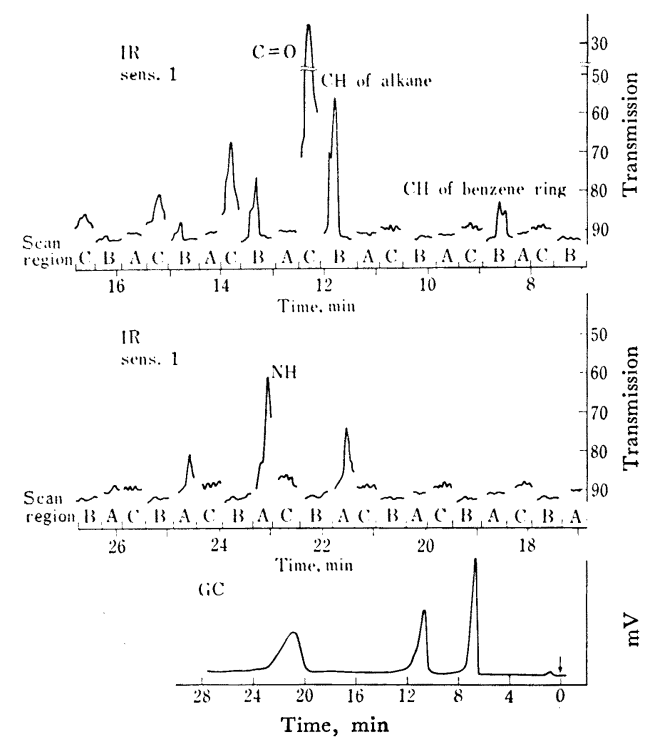

Fig. 11 Repetitive scanning of A-B-C series of GC-IR combination system

(A) $3520 \sim 3400 \mathrm{~cm}^{-1}$; $\quad$ (B) $3120 \sim 2840 \mathrm{~cm}^{-1}$; (C) $1730 \sim 1680 \mathrm{~cm}^{-1}$; Carrier gas : $\mathrm{H}_{2}, 18 \mathrm{ml} / \mathrm{min}$; Organic vapor : $\mathrm{CCl}_{4}$ condensed, $64 \mathrm{mg} / \mathrm{min}$; Sample : Benzene $(3 \mu l)$, methyl isobutyl ketone $(3 \mu l)$ and pyrrole $(4 \mu l)$; Column : Dioctyl phthalate, 25\%, $2.5 \mathrm{~m}$, inner diameter $4.5 \mathrm{~mm}$, temp. $147^{\circ} \mathrm{C}$ 
光光度計の改良（光源強度をあげる，赤外線の集光によ る微小七ルの使用など), 赤外顕微鏡の使用や液体セル 厚学增すことなどにより，さらに微量試料でじゅうぶえ 岕 GC-IR 測定が可能となるであるう。

$$
4 \text { 結語 }
$$

ガスクロマトグラフィーと赤外吸収スペクトル法の直 結を共㠜縮法により液体セルを用いて行ない良好な結果 忌得た。この方法により沸点約 $170^{\circ} \mathrm{C}$ 以下の試料の迅 速定性・定量分析が可能であることがわかった。また提 案したカ法はガスセルを用いて直結化を行なう方法に比 ベて簡便であること，セルの加熱が必要でないことや非 凝縮性ガスの体積の影響がないことなどの特長をるつ. また分取しついで赤外吸収スペクトル測定を行なう方法 に比べて所要時問が短時間であること, 通常分取の際え スト発生のため捕集率が非常に低くなるが有機溶媒蒸気 劣加光ての凝縮液化で注試料の効率よい捕集ができるこ と，さらに試料が少量でよいことなどの特長をもつ.

$\left(\begin{array}{l}\text { 昭和 } 43 \text { 年 } 4 \text { 月, 日本化学会第 } 21 \text { 年会; 昭 } \\ \text { 和 } 43 \text { 年 } 7 \text { 月, 分析化学討諭会におい䖾 }\end{array}\right)$

\section{交献}

1) D. Henneberg : Anal. Chem., 38, 495 (1966).

2) J. T. Watoson, K. Bieman : ibid., 37, 844 (1965).

3) J. T. Ballinger, T. T. Bartels, J. H. Taylor : J. Gas Chromatog., 6, 295 (1968).

4) J. E. Stewart, R. O. Brace, T. Johns, W. F. Ulrich : Nature, 186, 628 (1960).

5) H. Bober, K. Bürner : Z. Anal. Chem., 238, 1
(1968).

6) M. J. D. Low, S. K. Freeman : Anal. Chem., 39, 194 (1967).

7) M. St. C. Flett, J. Hughes : J. Chromatog., 11, 434 (1963).

8) J. U. White, N. L. Alpert, W. M. Ward, W. S. Gallaway: Anal. Chem., 31, 1267 (1959).

9) H. Feuerberg, M. Manjock, H. Weigel : $Z$. Anal. Chem., 219, 241 (1966).

$$
\text { tr }
$$

The combination of gas chromatography and infrared spectroscopy using a flow liquid cell. Takao TsudA, Hiroyuki MORI and Daido IsHII (Department of Applied Chemistry, Faculty of Engineering, Nagoya University, Chikusa-ku, Nagoya-shi)

Gas chromatography and infrared spectroscopy were combined to a unit process for rapid analysis of mixture of unknown substances by using a flow liquid cell. Organic vapor (carbon tetrachloride) was fed into hydrogen carrier eluted from the GC separation column, and the mixture was cooled in a small Liebig condenser (inner diameter $2 \mathrm{~mm}$, length $20 \mathrm{~mm}$ ) to collect the sample components with organic vapor. The condensed liquid was then led continuously to a flow liquid cell of a small volume and its spectrum was measured by scanning repetitively by the spectrometer. The change of transmittance was recorded by a strip chart recorder. By the restriction of slow scanning speed of the infrared spectrometer, the scanning was confined to several small regions. Experiments were carried out on benzene, octane, decane, methyl isobutyl ketone, pyrrole, etc. This new simple technique permits the rapid spectral examination of GC effluent and its qualitative and quantitative: analysis.

(Received Apr. 2, 1969) 